\title{
PENILAIAN KESEHATAN PUSAT KOPERASI KARTIKA SRIWIJAYA BERDASARKAN PERATURAN DEPUTI BIDANG PENGAWASAN KEMENTERIAN KOPERASI DAN UKM REPUBLIK INDONESIA NOMOR 06/PER/DEP.6/IV/2016
}

\author{
Mursalin $^{1}$, Yancik Syafitri ${ }^{2}$
}

1. Dosen fakultas ekonomi dan bisnis, Universitas PGRI, Sumatera Selatan

2, Dosen jurusan Akuntansi, Universitas Tridinanti, Sumatera Selatan

1)Email : mursalin@univpgri-palembang.ac.id

\section{Submitted: \\ $14 / 11 / 2021$ \\ Revised: \\ $01 / 12 / 2021$ \\ Accepted: \\ $20 / 12 / 2021$ \\ Online-Published: \\ $31 / 12 / 2021$}

INFORMASI ARTIKEL

\begin{abstract}
ABSTRAK
Penelitian ini bertujuan menilai kesehatan Pusat Koperasi Kartika Sriwijaya tahun buku 2019 berdasarkan Peraturan Deputi Bidang Pengawasan Kementerian Koperasi dan Usaha Kecil dan Menengah Republik Indonesia Nomor 06/Per/Dep.6/IV/2016 tentang Aspek Permodalan, Kualitas Aktiva Produktif, Manajemen, Likuiditas, Efisiensi, Kemandirian dan Pertumbuhan, dan Jatidiri Koperasi. Metode penelitian menggunakan deskriptif kualitatif. Sampel penelitian berupa laporan keuangan Pusat Koperasi Kartika Sriwijaya tahun buku 2019. Sumber data penelitian adalah data sekunder. Teknik pengumpulan data adalah wawancara dan dokumentasi. Teknik analisis data adalah deskriptif kualitatif. Berdasarkan hasil penelitian menunjukan bahwa penilaian kesehatan Pusat Koperasi Kartika Sriwijaya tahun buku 2019 mendapat skor akhir 60,5 yang mana skor tersebut dikategorikan dalam predikat dalam pengawasan dengan rincian : (1) aspek permodalan mendapatkan skor 12,00 dengan predikat cukup sehat; (2) aspek kualitas aktiva produktif mendapatkan skor 8,75 dengan predikat dalam pengawasan; (3) aspek manajemen mendapatkan skor 15,00 dengan predikat sehat; (4) aspek efisiensi mendapatkan skor 8,00 dengan predikat cukup sehat; (5) aspek likuiditas mendapatkan skor 3,75 dengan predikat dalam pengawasan khusus; (6) aspek kemandirian dan pertumbuhan mendapatkan skor 6,00 dengan predikat cukup sehat; dan (7) aspek jatidiri koperasi mendapatkan skor 7,00 dengan predikat cukup sehat.
\end{abstract}

Kata kunci: Permodalan, Kualitas Aktiva Produktif, Manajemen, Likuiditas, Efisiensi, Kemandirian dan Pertumbuhan, dan Jatidiri Koperasi.

\begin{abstract}
ABSTRACK
This study aims to assess the health of the Kartika Sriwijaya Cooperative Center for the 2019 financial year based on the Regulation of the Deputy for Supervision of the Ministry of Cooperatives and Small and Medium Enterprises of the Republic of Indonesia Number 06/Per/Dep.6/IV/2016 concerning Capital Aspects, Quality of Earning Assets, Management, Liquidity, Efficiency, Independence and Growth, and Cooperative Identity. The research method uses descriptive qualitative. The research sample is the financial report of the Kartika Sriwijaya Cooperative Center for the 2019 financial year. The source of the research data is secondary data. Data collection techniques are interviews and documentation. The data analysis technique is descriptive qualitative. Based on the results of the study, it was shown that the health assessment of the Kartika Sriwijaya Cooperative Center for the 2019 financial year received a final score of 60.5, where the score was categorized in the predicate under supervision with details: (1) the capital aspect scored 12.00 with the predicate quite healthy; (2) the quality aspect of earning assets gets a score of 8.75 with a predicate under supervision; (3) the management aspect gets a score of 15.00 with a healthy predicate; (4) the efficiency aspect gets a score of 8.00 with the predicate quite healthy; (5) the liquidity aspect gets a score of 3.75 with a predicate under special supervision; (6) aspects of independence and growth get a score of 6.00 with the predicate quite healthy; and (7) the identity aspect of the cooperative gets a score of 7.00 with the predicate quite healthy.
\end{abstract}

Keywords:Capital, Earning Asset Quality, Management, Liquidity,Efficiency, Independence and Growth, and Cooperative Identity. 


\section{A. PENDAHULUAN}

Perekonomian di Indonesia sekarang bertumbuh pesat, ditandai dengan berbagai jenis usaha atau perusahaan, baik berskala kecil, menengah, maupun berskala besar. Seiring berkembangnya suatu usaha atau perusahaan menuntut pula untuk berkembang di berbagai sektor. Setiap usaha atau perusahaan pasti ingin memperoleh laba yang sebesarbesarnya, dalam hal ini besar kecilnya keuntungan akan dikatakan sebagai tolak ukur apakah suatu usaha atau perusahaan telah bisa dikatakan berhasil atau belum. Sedangkan bagi manajer ini merupakan ukuran kesuksesan dalam mengelola usaha atau perusahaan yang dimiliki.

Demokrasi ekonomi di Indonesia memberikan kesempatan kepada orang atau lembaga perusahaan untuk berperan aktif dalam pembangunan perekonomian Indonesia. Salah satu lembaga ekonomi yang ikut serta dalam pembangunan perekonomian Indonesia adalah koperasi. Koperasi sebagai gerakan ekonomi rakyat yang dijalankan berdasarkan asas kekeluargaan sesuai dengan kepribadian bangsa indonesia.

Koperasi dianggap sebagai lembaga ekonomi yang sesuai kepribadian bangsa Indonesia. Tidak berlebihan jika koperasi dianggap sebagai soko guru atau pilar utama perekonomian Indonesia. Koperasi sebagai gerakan ekonomi rakyat dijalankan berdasarkan asas kekeluargaan. Setiap kegiatan ekonomi koperasi dimaksudkan untuk memenuhi keperluan dan meningkatkan kesejahteraan anggota dan masyarakat. Asas ini tidak dapat dilepaskan dari proses pembentukan koperasi yang merupakan kumpulan orang seorang, bukan modal.
Berdasarkan penelitian terdahulu yang dilakukan oleh Hodsay dan Yolanda (2019) yang berjudul "Analisis Penilaian Kesehatan Keuangan Koperasi Simpan Pinjam (KSP) Sejahtera SMK Muhamadiyah 2 Palembang", menunjukkan bahwa hasil penilaian koperasi tersebut dengan menggunakan beberapa aspek penilaian kesehatan selama tahun buku 2015-2017 secara berturut-turut dengan hasil ratarata 64,40 sehingga dikelompokan dalam kategori dalam pengawasan.

Berdasarkan pengamatan peneliti, Pusat Koperasi Kartika Sriwijaya merupakan salah satu koperasi yang bergerak pada bidang Koperasi Simpan Pinjam (KSP), dan melakukan kegiatan usaha penghimpun dana dari anggota dan juga menyalurkannya kepada anggota koperasi, dana tersebut dikelola dengan baik secara profesional sesuai dengan prosedur kehati-hatian. Kemudian setiap akhir tahun diadakan pemeriksaan dan laporan pertanggungjawaban pada Rapat Anggota Tahunan (RAT). Tujuan dari penelitian ini adalah untuk mengetahui penilaian kesehatan keuangan koperasi pada Pusat Koperasi Kartika Sriwijaya tahun buku 2019.

Untuk mengetahui penilaian kesehatan koperasi, maka penilaian kesehatan koperasi perlu dilakukan pada setiap akhir tahun. Untuk mengetahui kondisi kesehatan koperasi apakah dinyatakan sehat, cukup sehat, dalam pengawasan, dan dalam pengawasan khusus. Dengan melalui beberapa aspek penilaian kesehatan koperasi yaitu: Permodalan, Kualitas Aktiva Produktif, Manajemen, Efisiensi, Likuiditas, Kemandirian dan Pertumbuhan, dan Jatidiri Koperasi, menurut Peraturan Deputi Bidang Pengawasan Kementerian Koperasi dan UKM Republik Indonesia Nomor 06/Per/Dep.06/IV/2016. 


\section{B. METODE PENELITIAN}

Metode penelitian menggunakan deskriptif kualitatif, bertujuan untuk menganalisis laporan keuangan Pusat Koperasi Kartika Sriwijaya. Populasi dalam penelitian ini adalah laporan keuangan Pusat Koperasi Kartika Sriwijaya, sedangkan sampel penelitian adalah laporan keuangan Pusat Koperasi Kartika Sriwijaya tahun buku 2019. Teknik pengumpulan data dengan

\begin{tabular}{clc}
\hline No & Aspek yang Dinilai & Tahun 2019 \\
\hline 1 & Permodalan & 3,00 \\
\hline \multicolumn{2}{l}{ a. Rasio Modal Sendiri terhadap Total Aset } & 6,00 \\
\hline b. Rasio Modal Sendiri terhadap Pinjaman Diberikan yang Berisiko & 3,00 \\
\hline \multicolumn{2}{l}{ c. Rasio Kecukupan Modal Sendiri } & $\mathbf{1 2 , 0 0}$ \\
\hline Rerata
\end{tabular}

Sumber : Data diolah peneliti, 2021

a. Rasio Modal Sendiri terhadap Total Aset

Berdasarkan analisis yang telah dilakukan, menunjukan bahwa pada tahun 2019, rasio yang diperoleh sebesar $71,81 \%$ sehingga mendapat nilai 50 dengan skor 3,00.

b. Rasio Modal Sendiri terhadap Pinjaman Berisiko

Berdasarkan analisis yang telah dilakukan, menunjukan bahwa pada tahun 2019, rasio yang diperoleh sebesar $1539,60 \%$ sehingga mendapat nilai 20 dengan skor 6,0 . wawancara dan dokumentasi, dan teknik analisis data dalam penelitian ini dengan menggunakan rasio keuangan koperasi.

\section{HASIL DAN PEMBAHASAN}

1. Permodalan

Tabel 1. Hasil Penilaian Kesehatan Aspek PermodalanTahun 2019

\begin{tabular}{|c|c|c|}
\hline No & Aspek yang Dinilai & $\begin{array}{c}\text { Tahun } \\
2019\end{array}$ \\
\hline \multirow[t]{6}{*}{2} & Kualitas Aktiva Produktif & \\
\hline & $\begin{array}{l}\text { a. Rasio Volume Pinjaman pada Anggota terhadap Volume Pinjaman } \\
\text { Diberikan }\end{array}$ & 7,50 \\
\hline & b. Rasio Risiko Pinjaman Bermasalah terhadap Pinjaman yang Diberikan & 0,00 \\
\hline & c. Rasio Cadangan Risiko terhadap Pinjaman Bermasalah & 0,00 \\
\hline & d. Rasio Pinjaman yang Berisiko terhadap Pinjaman yang Diberikan & 1,25 \\
\hline & Rerata & 8,75 \\
\hline
\end{tabular}

a. Rasio Volume Pinjaman pada Anggota terhadap Volume Pinjaman Diberikan

Berdasarkan analisis yang telah dilakukan, menunjukan bahwa rasio c. Rasio Kecukupan Modal

Berdasarkan analisis yang telah dilakukan, menunjukan bahwa pada tahun 2019, rasio yang diperoleh sebesar $980,69 \%$ sehingga mendapat nilai 100 dengan skor 3,00.

\section{Kualitas Aktiva Produktif}

Tabel 2. Hasil Penilaian Kesehatan Aspek Kualitas Aktiva Produktif Tahun 2019 volume pinjaman pada anggota terha dap volume pinjaman diberikan pada tahun 2019, rasio yang diperoleh sebesar $55,75 \%$ sehingga mendapat nilai 75 dengan skor 7,50.

b. Rasio Risiko Pinjaman Bermasalah 
terhadap Pinjaman yang Diberikan

Berdasarkan analisis yang telah dilakukan, menunjukan bahwa pada tahun 2019, rasio yang diperoleh sebesar 274,68\% sehingga mendapat nilai 0 dengan skor 0,00 .

c. Rasio Cadangan Risiko terhadap Pinjaman Bermasalah

Berdasarkan analisis yang telah dilakukan, menunjukan bahwa pada laporan keuangan Pusat Koperasi Kartika Sriwijaya berdasarkan buku Rapat Anggota Tahunan (RAT) tahun 2019 tidak memiliki cadangan risiko. Oleh karena itu peneliti tidak memberi nilai pada rasio ini, sehingga diberikan nilai 0 dengan skor 0,00 .

d. Rasio Pinjaman yang Berisiko terhadap Pinjaman yang Diberikan Berdasarkan hasil analisis yang telah dilakukan, menunjukan bahwa pada tahun 2019, rasio yang diperoleh $274,68 \%$ sehingga mendapat nilai 25 dengan skor 1,25.

\section{Manajemen}

Tabel 3. Hasil Penilaian Kesehatan Aspek ManajemenTahun 2019

\begin{tabular}{clc}
\hline No & \multicolumn{1}{c}{ Aspek yang Dinilai } & $\begin{array}{c}\text { Tahun } \\
\mathbf{2 0 1 9}\end{array}$ \\
\hline $\mathbf{3}$ & Manajemen & \\
\hline \multicolumn{2}{c}{ a. Manajemen Umum } & 3,00 \\
\hline b. Manajemen Kelembagaan & 3,00 \\
\hline c. Manajemen Permodalan & 3,00 \\
\hline d. Manajemen Aktiva & 3,00 \\
\hline e. Manajemen Likuiditas & 3,00 \\
\hline Rerata & $\mathbf{1 5 , 0 0}$ \\
\hline
\end{tabular}

Sumber : Data diolah peneliti, 2021

Berdasarkan analisis yang telah dilakukan, menunjukan bahwa Pusat Koperasi Kartika Sriwijaya pada aspek manajemen tahun 2019 diperoleh skor sebesar 15,00, yang mana skor maksimalnya adalah 15 . Skor tersebut berada pada rasio berkisar 80-100, sehingga dikategorikan predikat sehat.
Berdasarkan perolehan skor tersebut menunjukan bahwa Pusat Koperasi Kartika Sriwijaya dari aspek manajemen telah menjalankan manajemen dengan baik pada tahun 2019 .

\section{Efisiensi}

Tabel 4. Hasil Penilaian Kesehatan Aspek Efisiensi Tahun 2019

\begin{tabular}{clc}
\hline No & \multicolumn{1}{c}{ Aspek yang Dinilai } & $\begin{array}{c}\text { Tahun } \\
\mathbf{2 0 1 9}\end{array}$ \\
\hline $\mathbf{4}$ & Efisiensi & \\
\hline & a. Rasio Beban Operasi Anggota terhadap Partisipasi Bruto & 4,00 \\
\hline b. Rasio Beban Usaha terhadap SHU Kotor & 4,00 \\
\hline c. Rasio Efisiensi Pelayanan & 0,00 \\
\hline Rerata & $\mathbf{8 , 0 0}$ \\
\hline
\end{tabular}

Sumber : Data diolah peneliti, 2021

a. Rasio Beban Operasi Anggota terhadap Partisipasi Bruto

Berdasarkan analisis yang telah dilakukan, menunjukan bahwa pada tahun 2019diperoleh rasio sebesar 0,24\% sehingga mendapat nilai 100 dengan skor 4,00.

b. Rasio Beban Usaha terhadap SHU Kotor

Berdasarkan analisis yang telah dilakukan, menunjukan bahwa pada 
tahun 2019 diperoleh rasio sebesar $6,03 \%$ sehingga mendapat nilai 100 dengan skor 4,00.

c. Rasio Efisiensi Pelayanan

Berdasarkan analisis yang telah dilakukan, menunjukan bahwa pada tahun 2019 diperoleh rasio sebesar
$80,64 \%$ sehingga mendapat nilai 0 dengan skor 0,00 .

\section{Likuiditas}

Tabel 5. Hasil Penilaian Kesehatan Aspek Likuiditas Tahun 2019

\begin{tabular}{clc}
\hline No & Aspek yang Dinilai & $\begin{array}{c}\text { Tahun } \\
\mathbf{2 0 1 9}\end{array}$ \\
\hline $\mathbf{5}$ & Likuiditas & \\
\hline & a. Rasio Kas & 2,50 \\
\hline b. Rasio Pinjaman yang Diberikan terhadap Dana yang Diterima & 1,25 \\
\hline Rerata & $\mathbf{3 , 7 5}$ \\
\hline
\end{tabular}

\section{a. Rasio Kas}

Berdasarkan analisis yang telah dilakukan, menunjukan bahwa pada tahun 2019 diperoleh rasio sebesar $459,68 \%$ sehingga mendapat nilai 25 dengan skor 2,50.

b. Rasio Pinjaman yang Diberikan terhadap Dana yang Diterima dilakukan, menunjukan bahwa pada tahun 2019diperoleh rasio sebesar 6,50\% sehingga mendapat nilai 25 dengan skor 1,25 .

\section{Kemandirian dan Pertumbuhan}

Tabel 6. Hasil Penilaian Kesehatan Aspek Kemandirian dan Pertumbuhan Tahun 2019

\begin{tabular}{clc}
\hline No & \multicolumn{1}{c}{ Aspek yang Dinilai } & $\begin{array}{c}\text { Tahun } \\
\mathbf{2 0 1 9}\end{array}$ \\
\hline $\mathbf{6}$ & Kemandirian dan Pertumbuhan & 3,00 \\
\hline \multicolumn{2}{l}{ a. Rentabilitas Aset } & 3,00 \\
\hline b. Rentabilitas Modal Sendiri & 0,00 \\
\hline c. Kemandirian Operasional Pelayanan & $\mathbf{6 , 0 0}$ \\
\hline Rerata
\end{tabular}

\section{a. Rasio Rentabilitas Aset}

Berdasarkan analisis yang telah dilakukan, menunjukan bahwa pada tahun 2019 diperoleh rasio sebesar $20,39 \%$ sehingga mendapat nilai 100 dengan skor 3,00.

b. Rasio Rentabilitas Modal Sendiri

Berdasarkan analisis yang telah dilakukan, menunjukan bahwa pada tahun 2019 diperoleh rasio sebesar 7,98\% sehingga mendapat nilai 100 dengan skor 3,00 .

c. Rasio Kemandirian Operasional Pelayanan

Berdasarkan analisis yang telah dilakukan, menunjukan bahwa pada laporan keuangan Pusat Koperasi Kartika Sriwijaya berdasarkan buku Rapat Anggota Tahunan (RAT) tahun buku 2019 tidak memiliki partisipasi netto. Oleh karena itu peneliti tidak memberi nilai pada rasio ini, sehingga diberikan nilai 0 dengan skor 0,00 .

\section{Jatidiri Koperasi}

Tabel 7. Hasil Penilaian Kesehatan Aspek Jatidiri Koperasi Tahun 2019 


\begin{tabular}{clc}
\hline No & Aspek yang Dinilai & Tahun 2019 \\
\hline $\mathbf{7}$ & Jatidiri Koperasi & \\
\hline a. Jatidiri Koperasi & 7,00 \\
\hline b. Rasio Promosi Ekonomi Anggota (PEA) & 0,00 \\
\hline Rerata & $\mathbf{7 , 0 0}$ \\
\hline
\end{tabular}

\section{a. Rasio Partisipasi Bruto}

Berdasarkan analisis yang telah dilakukan, menunjukan bahwa pada tahun 2019 diperoleh rasio sebesar $99,20 \%$ sehingga mendapat nilai 100 dengan skor 7,00.

b. Rasio Promosi Ekonomi Anggota (PEA)

Berdasarkan analisis yang telah dilakukan, menunjukan bahwa pada laporan keuangan Pusat Koperasi Kartika Sriwijaya berdasarkan Rapat Anggota Tahunan (RAT) tahun buku 2019 tidak terdapat Promosi Ekonomi Anggota (PEA). Oleh sebab itu peneliti tidak memberi nilai pada rasio ini, sehingga diberikan nilai 0 dengan skor 0,00 .

Berdasarkan hasil semua perhitungan diatas, maka penilaian kesehatan koperasi pada Pusat Koperasi

\begin{tabular}{cc}
\hline Skor & Predikat \\
\hline $80.00 \leq \mathrm{x} \leq 100$ & Sehat \\
\hline $66.00 \leq \mathrm{x}<80.00$ & Cukup Sehat \\
\hline $51.00 \leq \mathrm{x}<66.00$ & Dalam Pengawasan \\
\hline$<51.00$ & Dalam Pengawasan Khusus
\end{tabular}

Kartika Sriwijaya tahun buku 2019, menunjukan bahwa rasio permodalan mendapatkan skor 12,00 , rasio kualitas aktiva produktif mendapatkan skor 8,75, rasio manajemen mendapatkan skor 15,00, rasio efisiensi mendapatkan 8,00, rasio likuiditas mendapatkan skor 3,75, rasio kemandirian dan pertumbuhan mendapatkan skor 6,00, dan rasio jatidiri koperasi 7,00. Skor akhir dari beberapa aspek tersebut mendapatkan skor 60,5, yang berada pada rasio berkisar antara 51-66. Sehubungan dengan hasil penilaian tersebut, maka predikat penilaian kesehatan koperasi pada Pusat Koperasi Kartika Sriwijaya tahun buku 2019 dikategorikan pada predikat dalam pengawasan.

Tabel 8. Penetapan Predikat Kesahatan KSP dan USP

Sumber : Peraturan Deputi Bidang Pengawasan Kementerian Koperasi dan UKM RI Nomor 06/PER/DEP.6/IV/2016

Tabel 9. Rangkuman Penilaian Kesehatan

Pusat Koperasi Kartika Sriwijaya Tahun

2019 
Jurnal Ratri (Riset Akuntansi Tridinanti), Vol. 3, No. 1, hal. 40- 47, Juli - Desember 2021 p-ISSN 2715 - 0208

\begin{tabular}{|c|c|c|}
\hline No & Aspek yang Dinilai & $\begin{array}{c}\text { Tahun } \\
2019\end{array}$ \\
\hline \multirow[t]{4}{*}{1} & Permodalan & 12,00 \\
\hline & a. Rasio Modal Sendiri terhadap Total Aset & 3,00 \\
\hline & b. Rasio Modal Sendiri terhadap Pinjaman Diberikan yang Berisiko & 6,00 \\
\hline & c. Rasio Kecukupan Modal Sendiri & 3,00 \\
\hline \multirow[t]{5}{*}{2} & Kualitas Aktiva Produktif & 8,75 \\
\hline & a. Rasio Volume Pinjaman pada Anggota terhadap Volume Pinjaman Diberikan & 7,50 \\
\hline & b. Rasio Risiko Pinjaman Bermasalah terhadap Pinjaman yang Diberikan & 0,00 \\
\hline & c. Rasio Cadangan Risiko terhadap Pinjaman yang Diberikan & 0,00 \\
\hline & d. Rasio Pinjaman yang Berisiko terhadap Pinjaman yang Diberikan & 1,25 \\
\hline \multirow[t]{6}{*}{3} & Manajemen & 15,00 \\
\hline & a. Manajemen Umum & 3,00 \\
\hline & b. Manajemen Kelembagaan & 3,00 \\
\hline & c. Manajemen Permodalan & 3,00 \\
\hline & d. Manajemen Aktiva & 3,00 \\
\hline & e. Manajemen Likuiditas & 3,00 \\
\hline \multirow[t]{4}{*}{4} & Efisiensi & 8,00 \\
\hline & a. Rasio Beban Operasi Anggota terhadap Partisipasi Bruto & 4,00 \\
\hline & b. Rasio Beban Usaha terhadap SHU Kotor & 4,00 \\
\hline & c. Rasio Efisiensi Pelayanan & 0,00 \\
\hline \multirow[t]{3}{*}{5} & Likuiditas & 3,75 \\
\hline & a. Rasio Kas & 2,50 \\
\hline & b. Rasio Pinjaman yang Diberikan terhadap Dana yang Diterima & 1,25 \\
\hline \multirow[t]{4}{*}{6} & Kemandirian dan Pertumbuhan & 6,00 \\
\hline & a. Rentabilitas Aset & 3,00 \\
\hline & b. Rentabilitas Modal Sendiri & 3,00 \\
\hline & c. Kemandirian Operasional Pelayanan & 0,00 \\
\hline \multirow[t]{5}{*}{7} & Jatidiri Koperasi & 7,00 \\
\hline & a. Rasio Partisipasi Bruto & 7,00 \\
\hline & b. Promosi Ekonomi Anggota (PEA) & 0,00 \\
\hline & Skor Akhir & 60,5 \\
\hline & Predikat Kesehatan Koperasi Pusat Koperasi Kartika Sriwijaya Tahun 2019 & $\begin{array}{c}\text { Dalam } \\
\text { Pengawasan }\end{array}$ \\
\hline
\end{tabular}

\section{SIMPULAN DAN SARAN 1. Simpulan}

Aspek permodalan mendapat predikat cukup sehat, aspek kualitas aktiva produktif mendapat predikat dalam pengawasan, aspek manajemen mendapat predikat sehat, aspek efisiensi mendapat predikat cukup sehat, aspek likuiditas mendapat predikat dalam pengawasan khusus, aspek kemandirian dan pertumbuhan mendapat predikat cukup sehat dan jatidiri koperasi mendapat predikat cukup sehat. Dari hasil keseluruhan aspek penilaian kesehatan koperasi menunjukan bahwa Pusat Koperasi Kartika Sriwijaya tahun buku 2019 mendapat predikat dalam pengawasan. 


\section{Saran}

Terhadap aspek kualitas aktiva produktif yang mendapat predikat dalam pengawasan sebaiknya pengelola Pusat Koperasi Kartika Sriwijaya harus membuat peraturan yang lebih bijak dan prosedur yang lebih ketat pada saat anggota ingin mengajukan pinjaman dengan melihat agunan yang memadai, dan untuk aspek likuiditas untuk dapat melakukan tindakan cepat dalam mengelola rasio kas yang masih kurang baik supaya kondisi ini cepat terselesaikan.

\section{E. DAFTAR RUJUKAN}

Aryani, H, G., Setiadi, O, I., Hastyorini, R, I., Sari, K. (2015). Perkoperasian. Klaten: Cempaka Putih.

Deputi Bidang Pengawasan Kementerian Koperasi dan UKM Republik Indonesia (2016). Peraturan Deputi Bidang Pengawasan Kementerian Koperasi dan UKM Republik Indonesia Nomor 06/PER/DEP.6/2016 tentang Pedoman Penilaian Kesehatan Koperasi Simpan Pinjam dan Unit Simpan Pinjam Koperasi.

Hodsay, Z., dan Yolanda, Z. (2019). Analisis Penilaian Kesehatan Keuangan Koperasi Simpan Pinjam (KSP) Sejahtera SMK Muhamadiyah 2 Palembang. Jurnal Propit: Kajian Pendidikan Ekonomi dan Ilmu Ekonomi, 6(2), 114-125.

Tambunan, Toman, Sony, dan Tambunan, Hardi (2019).

Westriningsih. (2016). Mengupas Tuntas Koperasi Simpan Pinjam. Yogyakarta: Kompetensi Terapan Sinergi Pustaka 